\title{
Coronella austriaca (smooth snake) - mortality after prey ingestion
}

\author{
ALEKSANDRA KOLANEK ${ }^{1,2^{*}}$, MONIKA PASTRYKIEWICZ ${ }^{3}$, WOJCIECH BORAWSKI ${ }^{4}$ \\ \& STANISŁAW BURY ${ }^{1,5}$
}

\begin{abstract}
${ }^{1}$ NATRIX Herpetological Association, ul. Legnicka 65, 54-206 Wrocław, Poland
${ }^{2}$ Institute of Geography and Regional Development, University of Wrocław, pl. Uniwersytecki 1, 50-137 Wrocław, Poland ${ }^{3}$ Gogolin, Poland
\end{abstract}

${ }^{4}$ Department of Surgery, The Faculty of Veterinary Medicine, University of Environmental and Life Sciences, Wrocław, Poland ${ }^{5}$ Institute of Environmental Sciences, Jagiellonian University, Gronostajowa 7, 30-387 Kraków, Poland

*Corresponding author e-mail: aleksandra.kolanek@uwr.edu.pl

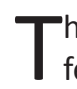
he smooth snake is a medium sized European species that feeds mainly on vertebrates. Reptiles and particularly lacertid lizards are considered as the main fraction of its diet (Reading \& Jofré, 2020). Legless reptiles are also preyed upon by the smooth snake, but such cases seem to be reported less frequently (Völkl et al., 2017). On 24 May 2019 a dead specimen of Coronella austriaca was found by the roadside in Gogolin (opolskie vovoideship, south-west Poland) with the tail of a slow-worm Anguis fragilis sticking out of its mouth. The snake had no external signs of being run over by car or bicycle, had no wounds and also did not look starved or weakened. X-ray examination was performed with the use of computed radiography by Konika Minolta (Regius Model 110s) and Siemens Polydoros LX 30 lamp (Fig. 1A). Computed tomography was performed with the use of the Siemens 16 slice CT scanner (Fig. 1B). The body length and diameter of both the snake and slow worm were measured and both were weighed.

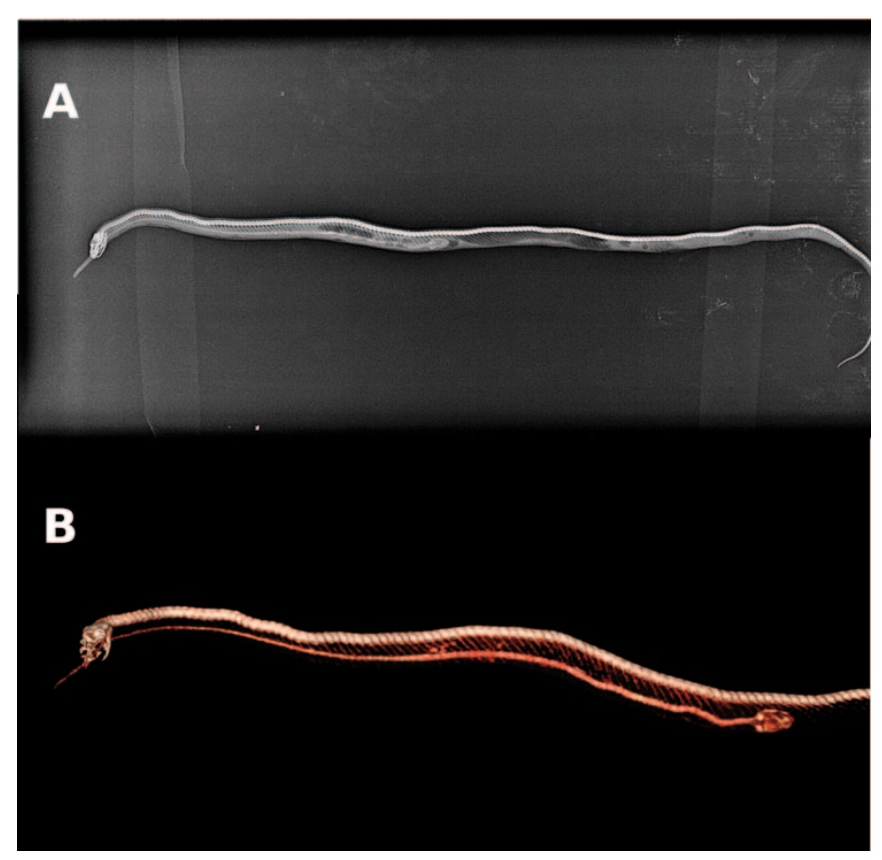

Figure 1. A. Total body radiographic image in latero-lateral projection of a dead C. austriaca and its prey, and B. CT image of the same animal, 3D image reconstruction (60mAs i $130 \mathrm{kV}, 0.6 \mathrm{~mm}$ SD)
Slow worms are not unusual prey items for smooth snakes, so mortality following ingestion of a slow worm seems unlikely and has never been reported previously. Greene (1983), who explored the maximum limits of the ratio prey mass/predator mass (WR), showed that the limiting ratio for non-venomous snakes is $W R=0.6$. Based on body measurements of the snake we collected $(\mathrm{SVL}=340.0 \mathrm{~cm}$; tail length $=76.0 \mathrm{~cm}$; head diameter $=12 \mathrm{~mm}$; weight $=14 \mathrm{~g}$ ) and the slow worm $(\mathrm{SVL}=86.0 \mathrm{~cm}$; tail length $=97.0 \mathrm{~cm}$; body diameter $=8 \mathrm{~mm}$; weight $=3 \mathrm{~g}$ ) giving a WR of approximately 0.2 which is far below the threshold suggested by Greene (1983). Thus the smooth snake which we collected should have been fully capable of swallowing prey of the size here recorded.

Indeed, larger prey items have been recorded as swallowed and digested by smooth snakes (Juszczyk, 1987). However, the skin of Anguis fragilis has osteoderms (Zylberberg \& Castanet, 1985); these reduce skin flexibility. This could constrain the capacity of the snake to both swallow such prey and to regurgitate it and could eventually lead to suffocation, which is the proposed cause of death here. Constraints of this kind might also result in lower size limits for swallowing prey such as slow worms compared to other prey types and explain why juvenile slow worms are more commonly ingested by smooth snakes than adults (Zimmermann, 1988).

Our observation suggests that ingestion of legless prey could carry the high cost of increased risk of mortality. This, in turn could provide an additional explanation of why ophiophagy, including cannibalism, is relatively rarely reported in snakes (Jackson et al., 2004) and why slow worms seem not to avoid shelters already inhabited by potential predators, i.e. smooth snakes (Kolanek et al., 2019) or Vipera berus (R.J. Hodges, personal communication).

\section{REFERENCES}

Greene, H. W. (1983). Dietary correlates of the origin and radiation of snakes. American Zoologist 23: 431-441.

Jackson, K., Kley, N. J. \& Brainerd, E. L. (2004). How snakes eat snakes: the biomechanical challenges of ophiophagy for the California kingsnake, Lampropeltis getula californiae (Serpentes: Colubridae). Zoology 107: 191-200. 
Juszczyk, W. (1987). Płazy i Gady Krajowe. Część 3: GadyReptilia. Państwowe Wydawnictwo Naukowe, Warszawa. $214 \mathrm{pp}$.

Kolanek, A., Bury, S., Turniak, E. \& Szymanowski, M. (2019). Age-dependent utilization of shelters and habitat in two reptile species with contrasting intraspecific interactions. Animals 9: 995.

Reading, C. \& Jofré, G. (2020). Smooth snake population decline and its link with prey availability. AmphibiaReptilia 41: 43-48.

Völkl, W., Käsewieter, D. \& Alfermann, D. (2017). Die Schlingnatter: Eine Heimliche Jägeri. Laurenti-Verlag, Bielefeld 2003. 151 pp.
Zylberberg, L. \& Castanet, J. (1985). New data on the structure and the growth of the osteoderms in the reptile Anguis fragilis L.(Anguidae, Squamata). Journal of Morphology 186: 327-342.

Zimmermann, P. (1988). Die schlingnatter (Coronella austriaca) im Weinberg "Hollstein" bei Freudenstein (Enzkreis, Baden-Württemberg). Carolinea - Beiträge zur naturkundlichen Forschung in Südwestdeutschland 46: 6-74.

Accepted: 2 April 2020 